\title{
VIABILITY OF THE EXTENDED TECHNOLOGY ACCEPTANCE MODEL: AN EMPIRICAL STUDY
}

\author{
Abu Yousuf Mohammed Atiquil Islam \\ Institute of Education \\ International Islamic University Malaysia (IIUM) \\ skyiium@yahoo.com
}

\begin{abstract}
The prime objective of this study is to validate the extended technology acceptance model (ETAM) by incorporating two intrinsic motivation attributes, namely, computer self-efficacy and satisfaction into the original TAM to compare its viability testing on their satisfaction of the wireless internet service at a university. Besides, it evaluates gender invariant of the causal structure of this extended TAM. A total of 285 students from five major faculties (Education, Human Sciences, Engineering, ICT and Economics) were taken as respondents. The questionnaire's reliability and validity were established through a RASCH analysis. The results as analyzed by Structural Equation Modelling (SEM) indicate that students' perceived ease of use had a statistically significant effect on their satisfaction. The study revealed that gender did not exert any influence as a moderating variable towards students' satisfaction in using Wireless Internet. The findings contributed to a better understanding of the TAM and technology satisfaction among students.
\end{abstract}

Keywords: Extended TAM, Wireless Internet, SEM, Cross-validation.

\section{INTRODUCTION}

The Technology Acceptance Model (TAM), proposed by Davis (1989), is one of the most profound frameworks frequently used to explain computerusage behavior and constructs associated with the acceptance of technology. The model affirms that the adoption of a technology is determined by the user's intention to use, which in turn is influenced by his or her attitudes towards, the technology. It is very likely that the variability in these attitudinal 
and behavioural constructs depends on the user's perceptions-perceived usefulness (PU) and perceived ease of use (PEU) (Ahmad, Basha, Marzuki, Hisham and Sahari, 2010). While PU indicates the extent to which the use of the technology will improve his or her performance, PEU represents the degree to which the technology seems to be free of effort (Davis, Bagozzi, \& Warshaw, 1989). This model postulates that behavioural intention mediates the effects of PU and PEU, the two constructs of extrinsic motivation as shown in Figure 1.

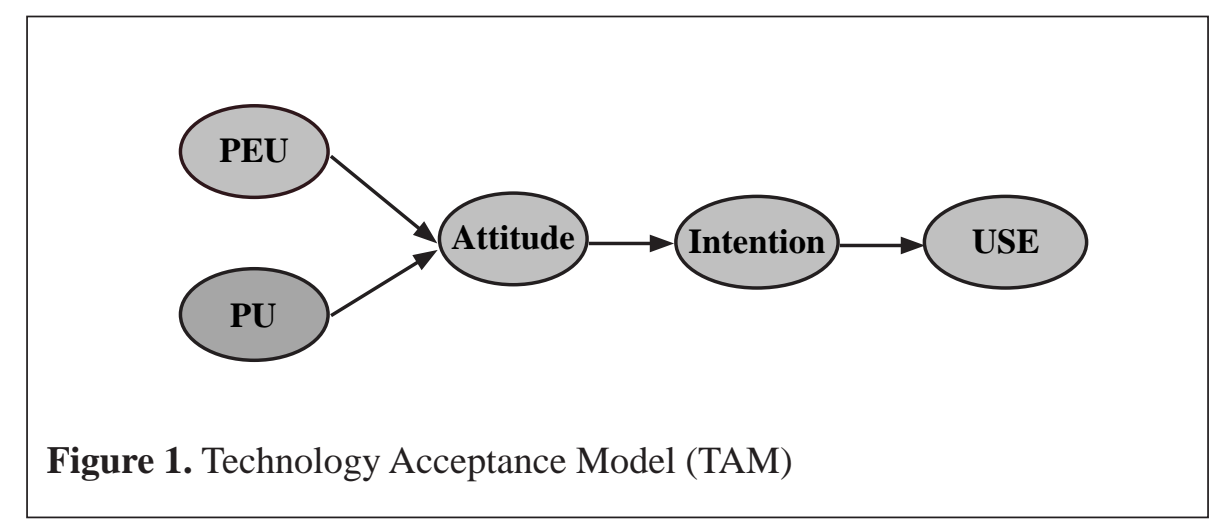

Throughout the years TAM has received extensive empirical support through validations and applications, for its power to predict the use of information systems (Davis, 1993; Taylor \& Todd, 1995b; Venkatesh \& Morris, 2000). However, researchers have also recognized that the generality of TAM fails to supply more meaningful information on users' opinions about a specific system.

According to Thompson, Compeau and Higgins (2006), perceived usefulness and perceived ease of use are not the only valid factors related to technology acceptance, especially with newer technologies. There is a need for TAM to incorporate additional factors or integrate with other IT acceptance models for improvement of its specificity and explanatory utility (Agarwal \& Prasad, 1998; Mathieson, 1991). Further research into the generalizability of the factors associated with technology acceptance and refinement of acceptance models has been recommended (Sun \& Zhang, 2006; Thompson et al., 2006). Previous studies also recommended that the Technology Acceptance Model (TAM) should be modified to comprise additional components required to explain more than 40 percent of technology acceptance and use (Legris, Ingham \& Collerette, 2003). Against this background, one purpose of the study was to validate an extended technology acceptance model (ETAM) on the data derived from students of a comprehensive public university in 
Malaysia. The second purpose of this study was to evaluate gender invariant of the causal structure of ETAM. This cross-validation procedure determined whether gender moderated the causal structure of the model, and hence the generality of ETAM.

\section{THE EXTENDED TECHNOLOGY ACCEPTANCE MODEL (ETAM)}

In the hypothesized extended technology acceptance model (ETAM) as shown in Figure 2, two other intrinsic motivation attributes - satisfaction and selfefficacy - were incorporated into the original TAM.

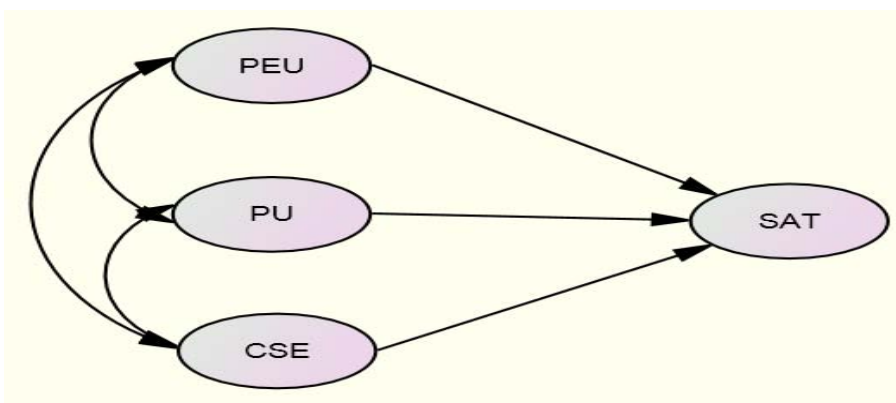

Figure 2. The Extended Technology Acceptance Model (ETAM)

\section{Perceived Ease of Use - Satisfaction}

The significance of perceived ease of use in technology adoption is highly pronounced in the technology acceptance model (TAM) proposed by Davis et al. (1989). Langeard, Bateson, Lovelock, and Eiglier (1981) observed that in choosing between available service-delivery options, the customers deem the effort expended in utilizing service delivery to be essential, with the superior the service delivery, the greater the customer satisfaction (Churchill \& Suprenant, 1982). In their respective studies, Szymanski and Hise (2000) and Dabholkar and Bagozzi (2002) considered convenience and ease of use to be important antecedents of e-satisfaction. In other related studies, Shamdasani, Mukherjee and Malhotra, (2008) regarded ease of use as one of the dimensions of service quality and explored its impact on consumer satisfaction in using self-service internet technologies. Along this line, Huang (2008) found the impact of e-consumers' perceived ease of use mediated by their behavioural attitude on their satisfaction statistically significant. As such, this study posits: H1: Perceived ease of use exerts a direct influence on students' satisfaction in adopting wireless technology. 


\section{Perceived Usefulness - Satisfaction}

In the extant literature, there have been a number of studies done vis-à-vis the effect of perceived usefulness on consumer satisfaction (Anderson, Fornell \& Lehmann, 1994). According to Huang (2008), perceived usefulness is observed to have an impact on consumer satisfaction mediated by their behavioural attitudes. Clemons and Woodruff (1992) stated that perceived value might directly translate into the formation of overall feelings of satisfaction. In their study, McDougall and Levesque (2000) corroborated this argument by noting that perceived value is a significant driver of customer satisfaction. It can therefore be inferred as:

H2: Perceived usefulness positively influences students' satisfaction in their acceptance of wireless technology.

\section{Computer Self-efficacy - Satisfaction}

According to Bandura and Schunk (1981), self-efficacy is defined as one's judgments about how well one can perform various courses of actions in different prospective situations fraught with many unpredictable and stressful elements. In the learning process, it conveys students' judgments about their cognitive capabilities to accomplish a specific academic task or particular goals (Schunk, 1991a). In the context of Internet use, it denotes a user's belief in his/her capabilities to organize and execute courses of Internet actions required to produce given attainments.

Research confirms propositions that self-efficacy influences the choice as to whether or not to engage in a task, the effort made in performing it, and the level of persistence required in accomplishing it (Bandura, 1977; Bandura \& Schunk, 1981; Delcourt \& Kinzie, 1993). According to Ahmad, Basha, Marzuki, Hisham and Sahari (2010, p. 271), the inclusion of self-efficacy as an intrinsic motivation construct offers 'deeper and richer understanding of why and how the technology is used'. Self-efficacy beliefs have been extensively reported as a prime factor in gauging the success or the lack thereof in the usage of computers by individuals (Cassidy \& Eachus, 2003).

In their study, Compeau and Higgins (1995) empirically tested a 10-item measure of computer self-efficacy (CSE) and found significant relationships between CSE and outcome expectations and use. According to a study performed among university students, Agarwal and Karahanna (2000) found CSE to be a key antecedent of perceived ease of use and was strongly influenced by an individual's ingenuity with IS. Along this line, Havelka's (2003) study perceived significant differences in CSE among students in different areas of 
academic discipline. In light of such findings, it is imperative on the part of the researchers to assess students' self-beliefs about their academic capabilities as being instrumental to their motivation and academic achievement (Pajares, 2002).

From various prior studies performed on the relationship between CSE and behavioural intention to use or infusion (Wu, Chang \& Guo, 2008; Ahmad et al., 2010) and the latter with individual satisfaction (Huang, 2008; Shamdasani, Mukherjee \& Malhotra, 2008), it is inferred that there is a relationship between CSE and satisfaction through the mediating effect of an individual's behavioural intention. It is thus hypothesized as:

H3: Computer self-efficacy positively influences students' satisfaction in accepting wireless technology.

\section{METHODOLOGY}

The data for this study was obtained through a survey questionnaire administered on students of a public university in Malaysia. A total of 285 students from five faculties (Education, Human Sciences, Engineering, ICT and Economics) were equally selected using the quota sampling technique among students having laptops as well as wireless connection. Since all the students are from the same university, the researchers were able to collect the data from the students residing at various students' hostels. Follow-up procedures were made among the respondents in case of any undue delay felt by the researchers.

The sample size was deemed adequate for the application of the structural equation modelling (SEM) to address the research objectives. Data analyses were performed with SPSS version 16.0. In order to analyse the structural relationships among the various constructs, AMOS software version 18.0 was applied.

\section{Research Instrument}

A questionnaire consisting of items validated from prior studies that measured four constructs of interests, namely, perceived ease of use, perceived usefulness, computer self-efficacy and satisfaction in adopting the wireless internet were developed and modified to address the research hypotheses. A five-point Likert-type scale asking the respondents of the extent of their agreement/disagreement of the items constituting the constructs in the questionnaire was used. 


\section{Perceived Ease of Use (PEU) and Perceived Usefulness (PU)}

Items for perceived ease of use and perceived usefulness in the survey were updated and measured by an instrument developed and validated by Davis (1989) and Chen, Gillenson and Sherrell (2002) and Venkatesh and Davis (1996).

\section{Computer Self-efficacy (CSE)}

Items for computer self-efficacy in the questionnaire were modified by combining survey items developed and validated by Compeau and Higgins (1995).

\section{Satisfaction (SAT)}

Items for satisfaction were adopted and modified by an instrument developed and validated by Chen and Wells (1999).

\section{Reliability and Validity of Instrument}

In order to measure the reliability and validity of the instruments, Rasch analysis was performed using Winsteps version 3.49. The results of the Rasch analysis indicate that (i) items and persons measured reliably $(r=.99$ and .88 respectively), (ii) all items measured in the same direction (pt measure corr. $>0.25$ ), (iii) most items showed good item fit and constructed a continuum of increasing intensity. The results also demonstrated that the majority items Infit and Outfit MNSQ were of acceptable range ( 0.50 to 1.5 ). Table 1 presents the list of the valid items, their mean, standard deviation, and Cronbach's alpha.

\section{RESULTS}

This section presents the three-stage results of the structural equation modelling that addressed the objectives of the study. It first assessed the validity of the measurement models and then estimated the full-fledged structural model of ETAM. Finally, the model was cross-validated to assess the moderating effect of gender on ETAM.

\section{Validity of the Measurement Models}

The confirmatory factor analysis (CFA) was run for each of the 4 measurement models namely, CFA-1 (PEU), CFA-2 (PU), CFA-3 (CSE) and CFA-4 (SAT); in each case, a few items were removed due to the violation of estimation. The 
revised 4 CFAs for each of these latent constructs showed an adequate fit to the empirical data [CFA-1: $(\chi 2(\mathrm{df}=2)=5.132 ; \mathrm{p}=0.077$; RMSEA $=0.074$; $\mathrm{CFI}=0.981$; TLI $=0.944)$; CFA-2: $(\chi 2(\mathrm{df}=5)=13.969 ; \mathrm{p}=0.016$; RMSEA $=0.079 ; \mathrm{CFI}=0.966 ; \mathrm{TLI}=0.933) ; \mathrm{CFA}-3:(\chi 2(\mathrm{df}=5)=18.228 ; \mathrm{p}=0.003$; RMSEA $=0.097 ;$ CFI $=0.969 ;$ TLI $=0.938 ;$ CFA-4: $(\chi 2(\mathrm{df}=2)=3.751 ; \mathrm{p}=$ 0.153 ; RMSEA $=0.056$; CFI $=0.993$; TLI $=0.979)$.

Table 1

Measurement of the Variables of the Hypothesized Model

\begin{tabular}{|c|c|c|c|c|c|}
\hline Item No & Item Label & Loadings & $M$ & $S D$ & $\alpha$ \\
\hline PU2 & $\begin{array}{l}\text { Using the Wireless Internet enables me } \\
\text { to download learning materials from the } \\
\text { internet. }\end{array}$ & 0.64 & 3.729 & 1.031 & \\
\hline PU7 & $\begin{array}{l}\text { Wireless Internet helps me access } \\
\text { online database to enhance my research. }\end{array}$ & 0.62 & 3.656 & 1.031 & 0.682 \\
\hline PU8 & $\begin{array}{l}\text { Using Wireless Internet allows me to } \\
\text { obtain multimedia facilities. }\end{array}$ & 0.59 & 3.512 & 1.019 & \\
\hline PU9 & $\begin{array}{l}\text { I can use Wireless Internet free-of- } \\
\text { charge at the campus. }\end{array}$ & 0.51 & 3.961 & 1.059 & \\
\hline PEU4 & $\begin{array}{l}\text { With Wireless Internet, I find it easy to } \\
\text { access online database to do research. }\end{array}$ & 0.54 & 3.361 & 1.134 & \\
\hline PEU5 & $\begin{array}{l}\text { It is easy for me to become skillful in } \\
\text { navigating the Internet using Wireless } \\
\text { facility. }\end{array}$ & 0.61 & 3.473 & 1.053 & 0.677 \\
\hline PEU9 & $\begin{array}{l}\text { Wireless Internet allows me to access } \\
\text { learning materials from LMS. }\end{array}$ & 0.67 & 3.736 & 1.029 & \\
\hline PEU10 & Wireless Internet is easy to use & 0.54 & 3.305 & 1.163 & \\
\hline SE1 & I am capable of using Wireless Internet. & 0.53 & 4.045 & 0.912 & \\
\hline SE4 & $\begin{array}{l}\text { I have the skills required to use Wireless } \\
\text { Internet to enhance the effectiveness of } \\
\text { my learning. }\end{array}$ & 0.68 & 3.915 & 0.945 & \\
\hline SE5 & $\begin{array}{l}\text { I know how to save and print journals/ } \\
\text { articles from online database using } \\
\text { Wireless Internet. }\end{array}$ & 0.84 & 3.926 & 0.999 & 0.806 \\
\hline SE6 & $\begin{array}{l}\text { I can easily go through the steps of } \\
\text { downloading software. }\end{array}$ & 0.81 & 3.782 & 1.028 & \\
\hline SAT2 & $\begin{array}{l}\text { Overall I am satisfied with the Wireless } \\
\text { Internet service provided at the } \\
\text { university. }\end{array}$ & 0.75 & 2.582 & 1.118 & \\
\hline SAT4 & $\begin{array}{l}\text { I am satisfied with wireless service } \\
\text { provided by the ITD. }\end{array}$ & 0.75 & 2.743 & 1.178 & 0.751 \\
\hline SAT5 & $\begin{array}{l}\text { I am satisfied accessing Wireless } \\
\text { Internet from the Mahallah. }\end{array}$ & 0.62 & 2.203 & 1.138 & \\
\hline
\end{tabular}




\section{Estimating the Full-fledged ETAM}

In order to examine the hypothesized model, all the four measurement models were integrated. The results indicated that the hypothesized fifteenitem measurement model was consistent with the data. However, the low and negative path coefficients of 0.19 (PU $>$ SAT) and -0.13 (CSE $>$ SAT) indicated that the two respective hypotheses $\mathrm{H} 2$ and $\mathrm{H} 3$ were not supported; this necessitated the revision of the model. As shown in the Figure 3, the revised model depicted goodness-of-fit to the empirical data as indicated by the following fit indices Chi-square, $\chi 2(\mathrm{df}=86)=154.962 ; \mathrm{p}<0.001$; RMSEA $=0.053 ; \mathrm{CFI}=0.940 ; \mathrm{TLI}=0.926$. The results indicated that the parameters of the revised model were free from offending estimates.

With the revised model, perceived ease of use exhibited significant influence on satisfaction. In addition, the interrelationships among the exogenous variables were tested in the structural model. The relationship between perceived ease of use (PEU) and perceived usefulness (PU) was found to be very significant ( $\beta$ $=0.75)$. The other two relationships, namely, between computer self-efficacy (CSE) and PEU, and CSE and PU, had also statistically significant influence $(\beta=0.42$, and $\beta=0.45$, respectively).

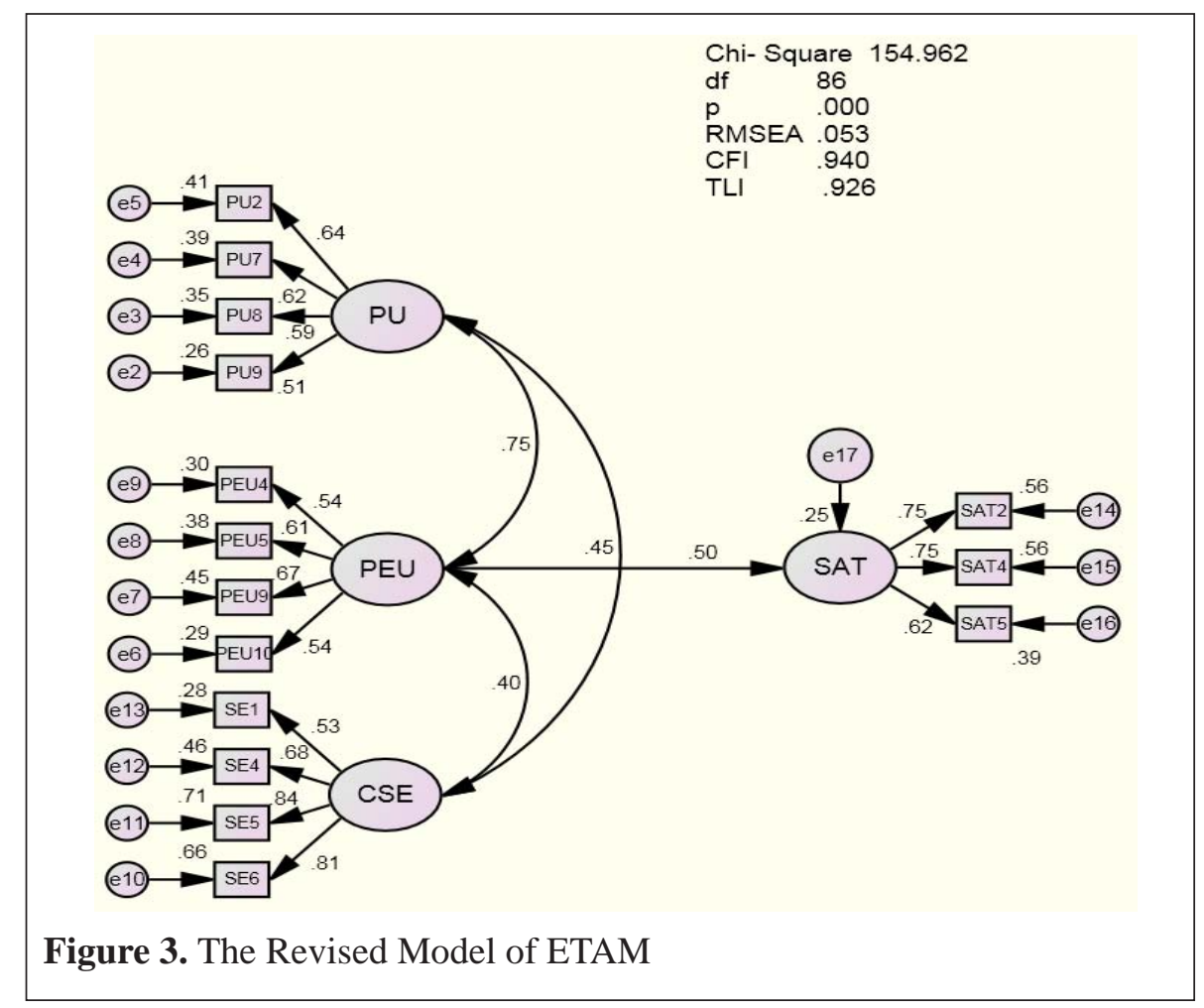




\section{Gender-invariant of the ETAM}

The second objective of this study was to examine the structural invariance of ETAM regarding the moderating effect of the gender dimension of the respondents. In order to test gender-invariant, a two-stage analysis i.e., configural and matric invariance, was conducted on both the male $(\mathrm{n} 1=127)$ and female $(\mathrm{n} 2=158)$ respondents. First, without constraining the structural paths, the results derived a baseline Chi-square value. Next, the structural paths were constrained to be equal for the male and female groups. The results for both constrained and unconstrained models were found to be consistent with the data as shown in Figure 4.

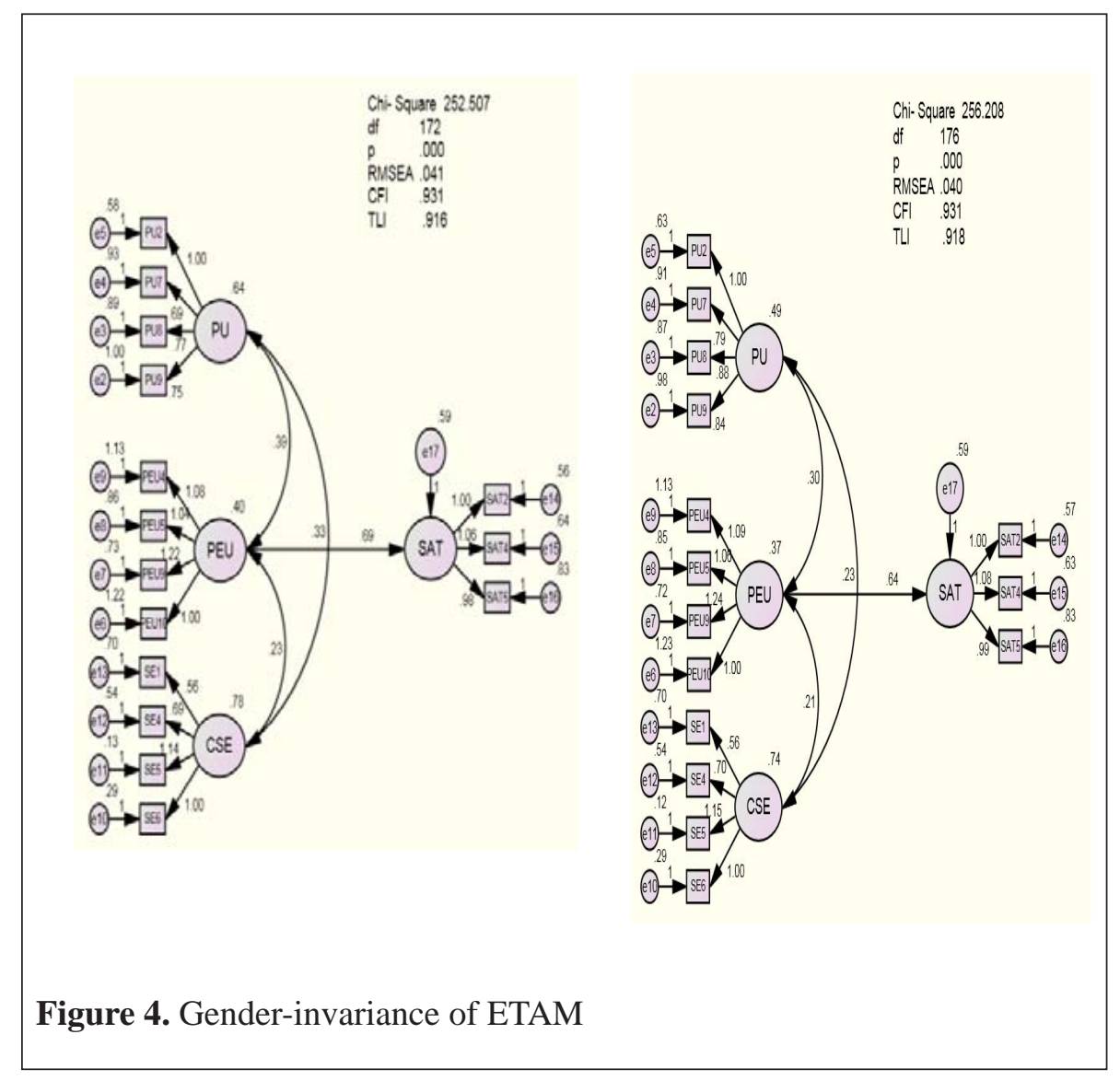

The analysis of this constrained ETAM produced another Chi-square value (256.208), which was then tested against the unconstrained value (252.507) for statistically significant differences. The invariance test across the male and female groups resulted in a statistically insignificant change in the Chi- 
square value, Chi-square $(\mathrm{df}=4)=3.701, \mathrm{p}>0.001$, as shown in Table 2 . This meant that gender did not interact with the exogenous variables to influence the students' satisfaction in using Wireless Internet. It is, therefore, reasonable to conclude that gender was not a moderating variable.

Table 2

Results of Critical Value of Chi-squared

\begin{tabular}{llcccc}
\hline Models & & Chi squared & df & $\begin{array}{c}\text { Critical } \\
\text { value }\end{array}$ & $\begin{array}{c}\text { Chi squared } \\
\text { change }\end{array}$ \\
\hline Gender & Unconstrained & 252.507 & 172 & 18.47 & 3.701 \\
& Constrained & 256.208 & 176 & & \\
\hline
\end{tabular}

\section{DISCUSSION}

The findings of the study have expanded the existing body of knowledge on TAM in several ways. First, the hypothesis that perceived ease of use having a positive direct influence on satisfaction stands validated. This comes in line with earlier studies (Szymanski \& Hise, 2000; Dabholkar \& Bagozzi, 2002), which found convenience, similar to the construct ease of use, to be a prominent factor in e-satisfaction. However, in their study, Shamdasani et al. (2008) observed that ease of use mediated by service quality did not show a high influence on satisfaction.

Second, as regards the effect of perceived usefulness and computer selfefficacy on satisfaction, these were revealed in insignificant path co-efficients, thereby invalidating the hypotheses. However, their impact on satisfaction might be reflected through their significant interrelationships with the other latent construct, i.e., perceived ease of use.

Third, the current study implies that the extended model explains the use of Wireless Internet among male and female users, as gender does not seem to constrain the generality of ETAM. This means that in an environment where students have access to use the Wireless Internet to facilitate learning, gender does not affect the students' satisfaction in using the Wireless Internet.

The finding was consistent with Ahmad et al. (2010) and Sam, Othman and Nordin (2005), who found no significant differences across the gender with respect to adopting technology. 


\section{CONCLUSION}

As information technology is increasingly used in education, its integration to learning has had immense significance in fostering technology-based education among the students of a university. By extending the technology acceptance model (TAM), this study examined the impact of the acceptance of wireless technology among the students' satisfaction. Two new latent constructs, namely computer self-efficacy and satisfaction were incorporated to extend the original framework of TAM. While the study validated one hypothesis - positive impact of perceived ease of use on satisfaction, it did not support the other two - impact of perceived usefulness and computer self-efficacy on satisfaction. The results demonstrated significant positive interrelationships among the three exogeneous constructs of the proposed framework. Regarding the gender invariance of the ETAM, the study revealed that gender did not appear to have any moderating effect on students' satisfaction in adopting the Wireless Internet.

\section{LIMITATIONS AND RECOMMENDATIONS}

This study was conducted among the students of a public university in Malaysia. In order to generalize the findings, it thus calls for the inclusion of a larger sample size comprising students of other universities as well; that would make the study more comprehensive in nature. Besides gender, future research on cross-validation of this extended model could be done to shed light on the moderating effects of other demographic attributes, such as nationalities, age, faculties, status of the study, etc., on students' satisfaction in using educational technology.

\section{REFERENCES}

Agarwal, R., \& Prasad, J. (1998). A conceptual and operational definition of personal innovativeness in the domain of information technology. Information Systems Research, 9 (2), 204-215.

Agarwal R., \& Karahanna, E. (2000). Time flies when you're having fun: Cognitive absorption and beliefs about information technology uses. MIS Quarterly, 24(4), 665-694.

Ahmad, T. B. T., Basha, K. M., Marzuki, A. M., Hisham, N. A., \& Sahari, M. (2010). Faculty's acceptance of computer-based technology: Crossvalidation of an extended model. Australian Journal of Educational Technology, 26(2), 268-279. 
Anderson E. W., Fornell, C., \& Lehmann, D. R. (1994). Customer satisfaction, market share and profitability. Journal of Marketing, 58(3), 53-66.

Bandura, A. (1977). Self-efficacy: Toward a unifying theory of behavioral change. Psychological review, 84, 191-125. Busch, T. (1995). Gender deferent in self-efficacy and attitude toward computers. Journal of Computing Research, 12, 147-158.

Bandura, A., \& Schunk, D. H. (1981). Cultivating competence, self-efficacy and intrinsic interest through self-motivation. Journal of Personality and Social Psychology, 41, 586-598.

Cassidy, S., \& Eachus P. (2003). The computer self-efficacy website. Retrieved from http://www.chssc.salford.ac.uk/healthSci/selfeff

Chen, L. D., Gillenson, M. L., \& Sherrell, D. L. (2002). Enticing online customers: An extended technology acceptance perspective. Information and Management, 39, 705-719.

Chen, Q., \& Wells, W. D. (1999). Attitude toward the site. Journal of Advertising Research, September/October, 27-37.

Churchill, G. A., \& Suprenant, C. (1982). An investigation into the determinants of customer satisfaction. Journal of Marketing Research, 19, 491-504.

Clemons, D. S., \& Woodruff, R. B. (1992). Broadening the view of consumers (dis) satisfaction: A proposed means - end disconfirmation model of CS/D. In Allen, C. T., Madden, T. J., Shimp, T. A., Howell, R. D., Zinkhan, G. M., \&. Heisley, D. D. (Eds.), Marketing theory and applications (pp 209-216). Chicago: American Marketing Association.

Compeau, R. D., \& Higgins, A. C. (1995). Computer self-efficacy: Development of a measure and initial test. MIS Quarterly, 19(2), 189-211.

Dabholkar, P. A., \& Bogazzi, R. (2002). An attitudinal model of technologybased self-service: Moderating effect of consumer traits and situational factors. Journal of Academy of Marketing Science, 30(3), 184-202.

Davis, F. D. (1989). Perceived usefulness, perceived ease of use and user acceptance of information technology. MIS Quarterly, 13(3), 319-340. 
Davis, F. D. (1993). User acceptance of information technology: System characteristics, user perceptions and behavioral impacts. International Journal of Man-Machine Studies, 38(3), 475-487.

Davis, F. Bagozzi, R. P., \& Warshaw, P. R. (1989). User acceptance of computertechnology: A comparison of two theoretical models. Management Science, 38(8), 982-1003.

Delcourt, M. A. B., \& Kinzie, M. B. (1993). Computer technologies in teacher education: The measurement of attitude and self-efficacy. Journal of Research and Development in Education, 27(1), 34-41.

Havelka, D. (2003). Predicting software self-efficacy among business students: A preliminary assessment. Journal of Information Systems Education, 14(2), 145-152.

Huang, E. (2008). Use and gratification in e-consumers. Internet Research, 18(4), 405-426.

Langeard, E., Bateson, J. E. G., \& Lovelock, C. H., \& Eiglier, P. (1981). Marketing of service: New insights from customers and managers. Cambridge, MA: Marketing Science Institute.

Legris, P., Ingham, J., \& Collerette, P. (2003). Why do people use information technology? A critical review of the technology acceptance model. Information \& Management, 40, 191-204.

Mathieson, K. (1991). Predicting user intention: Comparing the TAM with the theory of planned behavior. Information Systems Research, 2, 173-191.

McDougall, G. H. G., \& Levesque, T. (2000). Customer satisfaction with services: Putting perceived value into the equation. Journal of Service Marketing, 14(5), 392-401.

Pajares, F. (2002). Self-efficacy beliefs in academic contexts: An outline. Retrieved from http://www.emorv.edu/EDUCATlQN/mfp/efftalk.html

Sam, H. K, Othman, A. E. A., \& Nordin, Z. S. (2005). Computer self-efficacy, computer anxiety, and attitudes toward the internet: A study among undergraduates in Unimas. Educational Technology \& Society, 8(4), 205-219. http://www.ifets.info/journals/8_4/19.pdf 
Schunk, D. H. (1991a). Learning theories: An educational perspective. New York: McMillan.

Shamdasani, P., Mukherjee, A., \& Malhotra, N. (2008). Antecedents and consequences of service quality in consumer evaluation of self-service internet technology. The Service Industry Journal, 28(1), 117-138.

Sun, H., \& Zhang, P. (2006). The role of moderating factors in user technology acceptance. International Journal of Human Computer Studies, 64(2), 53-78.

Szymanski, D. M., \& Hise, R. T. (2000). E-satisfation: An initial examination. Journal of Retailing, 76(3), 309-322.

Taylor, S., \& Todd, P. (1995b). Understanding information technology usage: A test of competing models. Information Systems Research, 6(2), 144-176.

Thompson, R., Compeau, R. D., \& Higgins, C. (2006). Intentions to use information technologies: An integrative model. Journal of Organizational and End User Computing, 18(3), 25-47.

Venkatesh, V., \& Davis, F. D. (1996). A model of the antecedents of perceived ease of use: Development and test. Decision Science, 27(3), 451-482.

Venkatesh, V., \& Morris, G. M. (2000). Why don't men ever stop to ask for directions? Gender, social influence and their role in technology acceptance and usage behavior. MIS Quarterly, 24(1), 115-139.

Wu, W., Chang, H., \& Guo, C. (2008). An empirical assessment of science teacher's intention towards technology integration. Journal of Computers in Mathematics and Science Teaching, 27(4), 499-520. 